BRIEF REPORT

\title{
Deaths from international terrorism compared with road crash deaths in OECD countries
}

\section{N Wilson, $\mathbf{G}$ Thomson}

Injury Prevention 2005;11:332-333. doi: 10.1136/ip.2005.008979

Objective: To estimate the relative number of deaths in member countries of the Organisation for Economic Cooperation and Development (OECD) from international terrorism and road crashes.

Methods: Data on deaths from international terrorism (US State Department database) were collated (1994-2003) and compared to the road injury deaths (year 2000 and 2001 data) from the OECD International Road Transport Accident Database.

Results: In the 29 OECD countries for which comparable data were available, the annual average death rate from road injury was approximately 390 times that from international terrorism. The ratio of annual road to international terrorism deaths (averaged over 10 years) was lowest for the United States at 142 times. In 2001, road crash deaths in the US were equal to those from a September 11 attack every 26 days.

Conclusions: There is a large difference in the magnitude of these two causes of deaths from injury. Policy makers need to be aware of this when allocating resources to preventing these two avoidable causes of mortality.

$\mathrm{T}$ here is no doubt that international terrorism has contributed to injury and death in a number of member countries of the Organisation for Economic Co-operation and Development (OECD), and has crucial importance as a factor in policy making for all developed countries. Yet other forms of preventable injury are also important and warrant the attention of policy makers. As part of wider work on comparing the impact of international terrorism with other causes of preventable mortality, ${ }^{1}$ we compared the deaths from international terrorism in OECD countries with those from road crashes.

\section{METHODS}

Data on international terrorist attacks involving any deaths of non-perpetrators, for the most recent 10 year period (19942003) were obtained for OECD countries from the annual reports of the Counterterrorism Office of the US Department of State. ${ }^{2}$ The definition of terrorism used by the Department is: "Premeditated, politically motivated violence perpetrated against noncombatant targets by subnational groups or clandestine agents", with international terrorism meant as "terrorism involving citizens or the territory of more than one country". Minor adjustments to some of the mortality figures were made based on more detailed published data (as per the methodological details described elsewhere ${ }^{1}$ ). From these data, an average annual mortality burden was calculated for each country.

Data on injury mortality were based on the OECD International Road Transport Accident Database for the year
2001 (22 countries) and for 2000 (seven countries). ${ }^{3}$ There were no road crash data for one OECD country (Mexico). Rates were calculated using the most recent population data for each country from the WHO website. ${ }^{4}$

\section{RESULTS}

For the 29 OECD countries there were a total of 33 international terrorism attacks between 1994 and 2003 in which deaths occurred. The attacks incurred deaths at 38 specific sites (that is, some were coordinated) and there were a total of 3064 reported deaths (excluding perpetrators) (table 1). These attacks all occurred in 10 countries, with Turkey having the most fatal attacks $(n=11$, or one third of all the attacks in OECD countries).

When considering all of the 29 OECD countries, the annual death rate from road injury was approximately 390 times that from international terrorism (table 1). Out of the 10 countries suffering fatal international terrorism attacks, the ratio of annual road injury to international terrorism deaths ranged from 142 times for the United States, to 55300 times for Poland. In 2001, road deaths in the USA were equal to those from a September 11 type terrorist attack every 25.7 days. For all of these countries combined, the road mortality burden was equivalent to the impact of a September 11 attack every 9.1 days

\section{DISCUSSION}

The comparison between the causes of mortality was limited, given that only recent data (years 2000 and 2001) were used for road deaths, compared to data for international terrorism over a 10 year period. However, this would have underestimated the differences, as the average annual road crash mortality rates for the 1994-2003 period would probably have been generally higher than the results in this analysis. This was because between 1990 and 2000 there was a 21\% reduction in the absolute number of road crash deaths in 29 OECD countries. ${ }^{3}$

International terrorism and road crashes are both causes of fatal and non-fatal injuries and both have important economic consequences. The two may even be interrelated, given an analysis that suggests that the number of Americans who chose to avoid flying following 9/1 1 and lost their lives in road accidents was higher than the total number of passengers killed on the four fatal flights on 9/11. Important differences exist however, in that even though road crash victims can also suffer post-traumatic stress disorder, ${ }^{6}$ the psychological impacts of terrorism can be far more widespread. ${ }^{7}$ The relatively uneven distribution of international terrorism deaths across time and place means that particular episodes have special impacts. Terrorism also differs in that it can have substantial impacts on national and international security arrangements, and on political, social,

Abbreviation: $\mathrm{OECD}$, Organisation for Economic Co-operation and Development. 
Table 1 Mortality burdens from road crashes and international terrorism in OECD countries (ordered by severity of the road crash death rate)

\begin{tabular}{|c|c|c|c|c|c|}
\hline OECD country* & $\begin{array}{l}\text { Road crash deaths } \\
(2001)\end{array}$ & $\begin{array}{l}\text { Road crash deaths } \\
\text { per million } \\
\text { population (2001) }\end{array}$ & $\begin{array}{l}\text { Total deaths from } \\
\text { international terrorism } \\
\text { 1994-2003 }\end{array}$ & $\begin{array}{l}\text { International terrorism } \\
\text { deaths per million } \\
\text { population per year }\end{array}$ & $\begin{array}{l}\text { Ratio of annual road deaths to } \\
\text { annualized international } \\
\text { terrorism deaths } \ddagger\end{array}$ \\
\hline Greece & 2063 & $188 \dagger$ & 3 & 0.027 & 6877 \\
\hline Korea & 8097 & 171 & 0 & 0.0 & - \\
\hline Luxembourg & 76 & $170+$ & 0 & 0.0 & - \\
\hline Portugal & 1671 & 166 & 0 & 0.0 & - \\
\hline United States & 42116 & 145 & 2970 & 1.020 & 142 \\
\hline Poland & 5534 & 143 & 1 & 0.003 & 55340 \\
\hline Belgium & 1470 & $143+$ & 0 & 0.0 & - \\
\hline France & 8160 & 136 & 19 & 0.032 & 4295 \\
\hline Spain & 5517 & 135 & 1 & 0.002 & 55170 \\
\hline Czech Republic & 1334 & 130 & 0 & 0.0 & - \\
\hline Hungary & 1239 & 125 & 0 & 0.0 & - \\
\hline New Zealand & 455 & 118 & 0 & 0.0 & - \\
\hline Austria & 958 & 118 & 0 & 0.0 & - \\
\hline Slovakia & 614 & 114 & 0 & 0.0 & - \\
\hline Italy & 6410 & $112 \dagger$ & 0 & 0.0 & - \\
\hline Iceland & 32 & $111 \dagger$ & 0 & 0.0 & - \\
\hline Ireland & 411 & 105 & 0 & 0.0 & - \\
\hline Australia & 1748 & 89 & 0 & 0.0 & - \\
\hline Canada & 2766 & 88 & 0 & 0.0 & - \\
\hline Germany & 6977 & 85 & 3 & 0.004 & 23257 \\
\hline Finland & 433 & 83 & 0 & 0.0 & - \\
\hline Denmark & 431 & 81 & 0 & 0.0 & - \\
\hline Japan & 10060 & 79 & 0 & 0.0 & - \\
\hline Switzerland & 544 & 76 & 1 & 0.014 & 5440 \\
\hline Turkey & 5123 & $73+$ & 28 & 0.040 & 1830 \\
\hline Sweden & 554 & 62 & 0 & 0.0 & - \\
\hline Netherlands & 993 & 62 & 6 & 0.037 & 1655 \\
\hline Norway & 275 & 61 & 0 & 0.0 & - \\
\hline United Kingdom & 3580 & $61+$ & 32 & 0.054 & 1119 \\
\hline Total & 119641 & 114 & 3064 & 0.293 & 390 \\
\hline
\end{tabular}

*Excluding Mexico for which road crash mortality data was not included in the OECD International Road Transport Accident Database.

tThe most recent year for road crash mortality data was for the year 2000.

$\ddagger$ The figures in the second column divided by the figures in the fourth column (annualized).

and economic stability (factors that all need to be considered by policy makers).

Nevertheless, from an injury prevention perspective, this analysis indicates that a major difference between international terrorism and road crashes is the scale of the total mortality burden. The evidence base for interventions to prevent road crashes is also substantially greater. Policy makers need to consider these issues when allocating resources towards preventive interventions that can save lives from these two avoidable causes of mortality.

\section{Key points}

- This study estimated that annual deaths from road crashes in 29 OECD countries are substantially greater (390 times) than average annual deaths from international terrorism in these countries.

- Policy makers need to consider the relative mortality burdens when allocating resources towards preventive interventions that can save lives from these two avoidable causes of mortality.

\section{Authors' affiliations}

N Wilson, $\mathbf{G}$ Thomson, Department of Public health, Wellington School of Medicine \& Health Sciences, Otago University, Wellington, New Zealand

Competing interests: none.

Correspondence to: Dr N A Wilson, Wellington School of Medicine \& Health Sciences, PO Box 7343, Wellington, New Zealand; nwilson@ actrix.gen.nz

Accepted 22 August 2005

\section{REFERENCES}

1 Wilson $\mathbf{N}$, Thomson $\mathrm{G}$. The epidemiology of international terrorism involving fatal outcomes in developed countries (1994-2003). Eur J Epidemiol 2005;20:375-81.

2 US Department of State. Office of the Coordinator for Counterterrorism: Annual Reports (Appendix A Chronologies). http://www.state.gov/www/global/ terrorism/annual_reports.html and http://www.state.gov/s/ct/rls/pgtrpt/ and http://dosfan.lib.vic.edu/ERC/arms/PGT_report/ (accessed October 2005).

3 OECD Transport Division Road Transport Research Programme. Road safety performance-trends and comparative analysis. France: OECD RTR Programme, 2002, Available at http://www.oecd.org/dataoecd/56/32/ 2487308.pdf (accessed October 2005).

4 World Health Organization. Countries. Available at http://www.who.int/ country/en/ (accessed October 2005).

5 Gigerenzer G. Dread risk, September 11, and fatal traffic accidents. Psychol Sci 2004; 15:286-7.

6 Dougall AL, Ursano RJ, Posluszny DM, et al. Predictors of posttraumatic stress among victims of motor vehicle accidents. Psychosom Med 2001;63:402-11.

7 Schuster MA, Stein BD, Jaycox L, et al. A national survey of stress reactions after the September 11, 2001, terrorist attacks. N Engl J Med 2001;345:1507-12. 